\title{
Remembering Clay Christensen
}

\section{Daniel Forbes (University of Minnesota)}

KEYWORDS: Entrepreneurship, Innovation, Strategy.

Clay Christensen, the Harvard Business School educator who passed away in January 2020, changed the way people around the world think of innovation. Through widely-read books, such as "The Innovator's Dilemma," he popularized the idea of "disruptive innovation", a process by which entrepreneurs displace established, market-leading firms, upending entire industries along the way. Although Clay's terminology and examples gained wide acceptance among managers, scholars gave his work a more qualified reception. This recent blog post (https://digitopoly.org/2020/01/24/clay-christensen-mildmannered-disruptor/) by University of Toronto strategy professor Josh Gans (https://www.rotman.utoronto.ca/FacultyAndResearch/F aculty/FacultyBios/Gans) offers some thoughtful and personal reflections on Clay's life and work that can help entrepreneurs make sense of Clay's contributions - and their limitations - within a broader intellectual context.

Photo Courtesy of the Christensen Institute 